\title{
Isolation and identification of the immune-relevant ribosomal protein L10 (RPL10/QM-like gene) from the large yellow croaker Pseudosciaena crocea (Pisces: Sciaenidae)
}

\author{
X. Chen ${ }^{1,2}$, Y.Q.Su ${ }^{2}$, J. Wang², M. Liu ${ }^{2}$, S.F. Niu' ${ }^{2}$, S.P. Zhong ${ }^{2}$ and F. Qiu ${ }^{2}$ \\ ${ }^{1}$ Department of Marine technology, College of Ocean, \\ Nantong University, Nantong, China \\ ${ }^{2}$ State Key Laboratory of Marine Environmental Science, \\ College of Oceanography and Environmental Science, \\ Xiamen University, Xiamen, China \\ Corresponding author: J. Wang \\ E-mail: junw@xmu.edu.cn
}

Genet. Mol. Res. 11 (4): 3755-3765 (2012)

Received February 17, 2012

Accepted August 21, 2012

Published October 15, 2012

DOI http://dx.doi.org/10.4238/2012.October.15.7

\begin{abstract}
In order to investigate the immune role of ribosomal protein L10 (RPL10/QM-like gene) in marine fish, we challenged the large yellow croaker Pseudosciaena (= Larimichthys) crocea, the most important marine fish culture species in China, by injection with a mixture of the bacteria Vibrio harveyi and V. parahaemolyticus (3:1 in volume). Microarray analysis and real-time PCR were performed 24 and $48 \mathrm{~h}$ post-challenge to isolate and identify the QM-like gene from the gill $P$. crocea (designated PcQM). The expression level of the PcQM gene did not changed significantly at $24 \mathrm{~h}$ post-challenge, but was significantly downregulated at $48 \mathrm{~h}$ post-challenge, suggesting that the gene had an immune-modulatory effect in $P$. crocea. Full-length PcQM cDNA and genomic sequences were obtained by rapid amplification of cDNA ends (RACE)-PCR. The sequence of the PcQM gene clustered together with
\end{abstract}


those of other QM-like genes from other aquatic organisms, indicating that the QM-like gene is highly conserved in teleosts.

Key words: Immune role; Microarray; Pathogen; Pseudosciaena crocea; Ribosomal protein

\section{INTRODUCTION}

The ribosomal protein L10 (RPL10) was originally isolated as a putative Wilms' tumor suppressor and designated the QM gene (Dowdy et al., 1991). The higher expression level of the QM gene in non-tumorigenic Wilms' cells than that in tumorigenic cells suggested that the QM gene product was a putative tumor suppressor. Increasing evidence suggested that the QM-like genes have multiple extra-ribosomal functions during cell growth, differentiation, and apoptosis (Kaneko et al., 1992; Wool, 1996; Eisinger et al., 1997; Chavez-Rios and Vargas-Mejia, 2000; Green et al., 2000). Meanwhile, studies have showed that QM-like genes play an important immune role in organisms, including plants, invertebrates, and teleosts. For example, the QM-like gene from the plant Arabidopsis thaliana is an important component of NSP-interacting kinasemediated antiviral signaling (Rocha et al., 2008). The AbQM from the abalone Haliotis discus discus responds to facilitate a defensive effect against pathogenic infection (Oh et al., 2010). The GcQM from the grass carp Ctenopharyngodon idella plays an important role in immune defense associated with anti-bacteria and anti-viruses (Wen et al., 2005).

Currently, the large yellow croaker Pseudosciaena (=Larimichthys) crocea is the most important marine fish culture species in China, based on the approximate annual production of 70,000 tons (Liu and Sadovy de Mitcheson, 2008). Serious epidemics that emerged in cultured $P$. crocea juveniles have caused great economic losses (Wang et al., 2001; Jin et al., 2002). Common pathogens such as Vibrio harveyi and V. parahaemolyticus have been reported to infect $P$. crocea and other marine fishes cultured in China, causing epidermal hemorrhages, skin ulceration, and abdominal bleeding in hosts (Li et al., 2010; Mao et al., 2010).

The objective of this study was to investigate the immune role of the QM-like gene in $P$. crocea (PcQM) through juvenile challenge with a bacterial mixture of $V$. harveyi and $V$. parahaemolyticus. DNA microarray analysis and real-time PCR were performed post-challenge to isolate and identify the QM-like gene in the P. crocea gill. Gill tissue was selected for analysis because it has been reported to be the major organ of the mucosal immune system (dos Santos et al., 2001; Koppang et al., 2003; Ohta et al., 2004; Chou et al., 2008; Haugarvoll et al., 2008; Tobback et al., 2010).

\section{MATERIAL AND METHODS}

\section{Rearing fish and challenge experiment}

Juveniles of $P$. crocea (average body weight $200 \mathrm{~g}$ ) were bought from Sanduao $\left(26^{\circ} 40^{\prime} 19^{\prime \prime} \mathrm{N}, 119^{\circ} 43^{\prime} 19^{\prime \prime} \mathrm{E}\right)$, Ningde City, Fujian, China, and reared in our laboratory with filtered seawater. After a 7-day acclimatization period, the juveniles without external wounds on the body were selected and divided into 2 groups. In the challenge group, juveniles $(\mathrm{N}=$ 6) were challenged by injection with $0.2 \mathrm{~mL} / 100 \mathrm{~g}$ body weight bacterial mixture containing 
$V$. harveyi and $V$. parahaemolyticus ( $3: 1$ volume). In the control group, juveniles $(\mathrm{N}=6)$ were challenged with $0.2 \mathrm{~mL} / 100 \mathrm{~g}$ body weight sterilized phosphate-buffered saline ( $\mathrm{pH} 7.4)$.

Juveniles $(\mathrm{N}=3)$ from each group were sampled randomly at 24 and $48 \mathrm{~h}$ post-challenge, respectively, and the gill tissues from the same group sampled at the same time were pooled and preserved in RNAfixer (BioTeke, China) at $-20^{\circ} \mathrm{C}$ for further analyses.

\section{Extraction of total RNA}

Total RNA was extracted from $70 \mathrm{mg}$ P. crocea gill according to the TRIzol protocol (Invitrogen, USA), purified using an RNeasy Mini Kit (Qiagen, Germany) and checked with $1 \%$ formaldehyde-denatured agarose gel with ethidium bromide staining. To quantify the total RNA extracted, the optical density at $260 / 280 \mathrm{~nm}$ was determined by an Ultrospec 2100 Pro Spectrophotometer (Amersham Bioscience, USA).

\section{Microarray scanning of the PcQM gene}

The cDNA probes were synthesized by reverse transcription of $10 \mu \mathrm{g}$ total RNA using a SuperScript Indirect cDNA Labeling System (Invitrogen) and labeled with Cy5 for the challenge group and $\mathrm{Cy} 3$ for the control group (Amersham Bioscience), respectively. The gene chip hybridization procedures were according to Chou et al. (2008). The hybridized chips were scanned by a GenePix scanner (Molecular Devices, USA), and the images were analyzed using the GenePix and GeneSpring software (Agilent Technologies, USA). The significant Analysis of Microarray software (SAM 3.02; Standford University, USA) was used to determine the statistical significances.

\section{Amplification of the PcQM gene fragment}

The first strand of cDNA was synthesized using a RevertAid ${ }^{\mathrm{TM}} \mathrm{H}$ Minus First-Strand cDNA Synthesis Kit (Fermentas, USA) and amplified by PCR. The PCR was conducted using the degenerate primers QMP_forward and QMP_reverse (Table 1), which were designed according to Chen et al. (2011). Amplification was performed in a 50- $\mu \mathrm{L}$ mixture containing 5 $\mu \mathrm{L} 10 \mathrm{X}$ Taq buffer, $4 \mu \mathrm{L} 2.5 \mathrm{mM}$ of each dNTP mix, $4 \mu \mathrm{L} 25 \mathrm{mM} \mathrm{MgCl}, 0.25 \mu \mathrm{L} 5 \mathrm{U} / \mu \mathrm{L}$ Taq polymerase (Takara, Japan), $2 \mu \mathrm{L} 20 \mu \mathrm{M}$ each of forward and reverse primers, $1.5 \mu \mathrm{L}$ cDNA template, and $33.25 \mu \mathrm{L}$ sterile double-distilled water. The PCR conditions were as follows: initial denaturation at $94^{\circ} \mathrm{C}$ for $5 \mathrm{~min}$, followed by 35 cycles of $94^{\circ} \mathrm{C}$ for $30 \mathrm{~s}, 50^{\circ} \mathrm{C}$ for 30 $\mathrm{s}$, and $70^{\circ} \mathrm{C}$ for $1 \mathrm{~min}$, and $72^{\circ} \mathrm{C}$ for $10 \mathrm{~min}$ for the final extension. The PCR products were electrophoresed on a $1.5 \%$ agarose gel, stained with ethidium bromide, and photographed on an ImageQuant Scanner (GE Healthcare, USA).

\section{Analysis of the PcQM gene by real-time PCR}

The expression level of PcQM mRNA was estimated using the Mx3000P QPCR system (Stratagene, USA). Two primer pairs, qRT_forward and qRT_reverse, and Actin_forward and Actin_reverse (Table 1) were optimized to increase the specificity of the reaction. Cycling conditions were as follows: $95^{\circ} \mathrm{C}$ for $10 \mathrm{~s}$, followed by 30 cycles of $95^{\circ} \mathrm{C}$ for $5 \mathrm{~s}$ and $60^{\circ} \mathrm{C}$ for 
$30 \mathrm{~s}$. The final reaction volume was $25 \mu \mathrm{L}$. Each measurement was performed in triplicate. PcQM gene expression levels obtained were first normalized by mRNA expression of $\beta$-actin, and the relative mRNA expression of $\mathrm{PcQM}$ was then presented in relation to the control group using the $2^{-\Delta \Delta C \mathrm{CT}}$ method (Livak and Schmittgen, 2001).

\section{Cloning of full-length PcQM cDNA}

Full-length PcQM cDNA was obtained by the rapid amplification of cDNA ends (RACE)-PCR method. The primers QM5'_T, QM5'_O, QM5'_I, Adaptor3', and Tdaptor3' were designed based on Sambrook and David (2001) and Scotto-Lavino et al. (2006), and QM5'_1, QM5'_2, QM3' 1, and QM3' 2 were based on the PcQM cDNA fragment of this study (Table 1). We performed 5'- and 3'-RACE-PCR according to Sambrook and David (2001). The PCR products were analyzed as described in the amplification of the PcQM gene fragment section.

\section{Isolation of the PcQM genomic DNA}

The PcQM genomic DNA was isolated from the P. crocea gill based on a standard protocol (Sambrook and David, 2001). The primers GP_forward1, GP_reverse1, GP_forward2, and GP_reverse2 (Table 1) were obtained from the 5'- and 3'-non-coding region and the middle sequence of the full-length cDNA fragment. The PCRs were conducted in a total volume of $50 \mu \mathrm{L}$ containing $1 \mu \mathrm{L}$ DNA, $5 \mu \mathrm{L} \mathrm{10X} \mathrm{Taq} \mathrm{buffer,} 1.5 \mathrm{mM} \mathrm{MgCl}_{2}$, and $20 \mu \mathrm{M}$ of each primer. Cycling conditions were $95^{\circ} \mathrm{C}$ for $5 \mathrm{~min}, 35$ cycles of $95^{\circ} \mathrm{C}$ for $45 \mathrm{~s}$ and $60^{\circ} \mathrm{C}$ for $45 \mathrm{~s}$, and $72^{\circ} \mathrm{C}$ for $7 \mathrm{~min}$ for the final extension. The PCR products were analyzed as described in the Amplification of the PcQM gene fragment section and purified using SNAP spin columns (Invitrogen).

\begin{tabular}{lll}
\multicolumn{2}{c}{ Table 1. The sequences and functions of primers used for polymerase chain reaction (PCR). } \\
\hline Primer & Sequence (5'-3') & Function \\
\hline QMP_forward & TTCMAGKTYCCTGGACRCCA & cDNA amplification \\
QMP_reverse & CTGSCGNCCWGMGAACTTG & Real-time PCR \\
\hline qRT_forward & CCTGCGGTAAGGACGGTTTC & \\
qRT_reverse & AAAGCACCACGCATTCCAGT & \\
Actin_forward & GCCCAGAGCAAGAGGGGTA & \\
Actin_reverse & ATCACCGGAGTCCATGACA & 5'-RACE-PCR \\
\hline QM5'_T & CCAGTGAGCAGAGTGACGAGGACTCGAGCTCAAGC(T) ${ }_{17}$ & \\
QM5'_O & CCAGTGAGCAGAGTGACG & \\
QM5'_I & GAGGACTCGAGCTCAAGC & \\
QM5'_1 & CCAGTCTGGAGCCTATCAGCT & 3'-RACE-PCR \\
QM5'_2 & GCTCTGGAGGCTGCCCGTAT & \\
\hline Tdaptor3' & GACTCGAGTCGACATAGA(T) ${ }_{17}$ & \\
Adaptor3' & GACTCGAGTCGACATAG & \\
QM3'_1 & GACTCGAGTCGACATAG & Genomic sequence amplification \\
QM3'_2 & AGACTGGAATGCGTGGTGCT & \\
\hline GP_forward 1 & CCTCCATTAGTTCGCAACCATG & \\
GP_reverse 1 & GTACTTGTTAGCACAGATACGG & \\
GP_forward 2 & GGGCAGGAAGAAGGCCAAGGT & \\
GP_reverse 2 & CTGCAGCAGCTCTAGACGGCATG & \\
\hline
\end{tabular}

RACE $=$ rapid amplification of cDNA ends. 


\section{Phylogenic analysis of the PcQM sequence}

To determine the relatedness of $P$. crocea PcQM with other known QM-like homologous genes from both freshwater and marine organisms in GenBank, including the abalones $H$. discus discus and $H$. diversicolor supertexta, pearl oysters Pinctada fucata and P. martensi, sea urchin Strongylocentrotus purpuratus, shrimps Marsupenaeus japonicus and Penaeus monodon, lancelet Branchiostoma floridae, lamprey Petromyzon marinus, teleosts such as salmons Oncorhynchus masou formosanus and Salmo salar, grass carp C. idella, zebra fish Danio rerio, pike Esox lucius, channel catfishes Ictalurus furcatus and I. punctatus, red drum Sciaenops ocellatus, sole Solea senegalensis, and puffer fish Tetraodon nigroviridis, the amino acids (aa) of the QM-like protein were aligned by the ClustalX 1.83 software. A phylogenetic tree was constructed using the MEGA 4.0 software with the neighbor-joining method. Amino acid sequence percentage identities of the aquatic organisms used for comparison were analyzed by the DNAStar software.

\section{RESULTS}

\section{Microarray}

The purified total RNA density of $P$. crocea at $260 / 280 \mathrm{~nm}$ was $1.8-2.0$. Thirty-nine genes were upregulated and 37 genes downregulated at $24 \mathrm{~h}$ post-challenge, while 43 genes were upregulated and 76 genes downregulated at $48 \mathrm{~h}$ post-challenge. Some genes with possible immune roles, such as QM-like (designated PcQM), MHCII, and CD3zeta-1 were found; $\mathrm{PcQM}$ was downregulated at $48 \mathrm{~h}$ post-challenge.

\section{PcQM gene expression}

The amplification curve showed that the efficiency of all PCRs was identical and that the specificity of the reactions was good. The P. crocea PcQM expression levels between the challenge and control groups at $24 \mathrm{~h}$ post-challenge did not differ $(\mathrm{P}>0.05)$; however, the challenge group exhibited a significantly lower PcQM expression level than that of the control group at $48 \mathrm{~h}$ post-challenge $(\mathrm{P}<0.05)$ (Figure 1$)$.

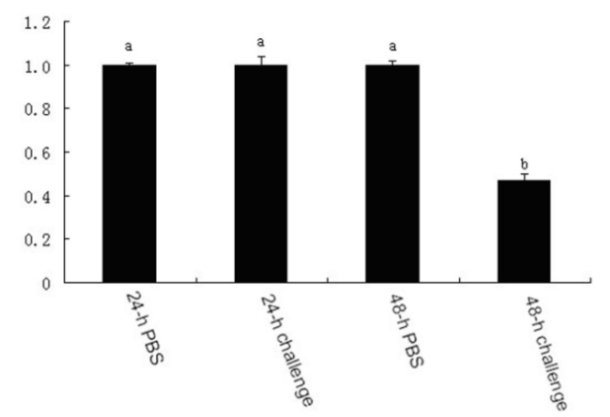

Figure 1. Relative expression of the PcQM gene from the gill of Pseudosciaena crocea at 24 and $48 \mathrm{~h}$ postchallenge with a bacterial mixture of Vibrio harveyi and $V$. alginolyticus $(3: 1)$ through muscle injection. Error bars represent the standard deviation of the triplicate-pooled samples. Different letters indicate the significant difference $(\mathrm{P}<0.05)$ between the challenge and control groups. $\mathrm{PBS}=$ phosphate-buffered saline. 


\section{Full-length PcQM cDNA sequence}

The full-length PcQM cDNA sequence was obtained (GenBank accession No. FJ455761) and contained $737 \mathrm{bp}$, including a 19-bp 5'-untranslated region (UTR) and a 70bp 3'-UTR obtained using 5'- and 3'-RACE-PCR. There was a start codon (ATG) and a stop codon (TAG) in the sequence (Figure 2). The ORF contained 648 bp, encoded 215 aa with a molecular weight of $24.62 \mathrm{kDa}$ and an isoelectric point of 10.138. In the aa sequence, there were 45 strongly basic (+) aa (K, R), 17 strongly acidic (-) aa (D, E), 66 hydrophobic aa (A, I, $\mathrm{L}, \mathrm{F}, \mathrm{W}, \mathrm{V})$, and 42 polar aa (N, C, Q, S, T, Y).
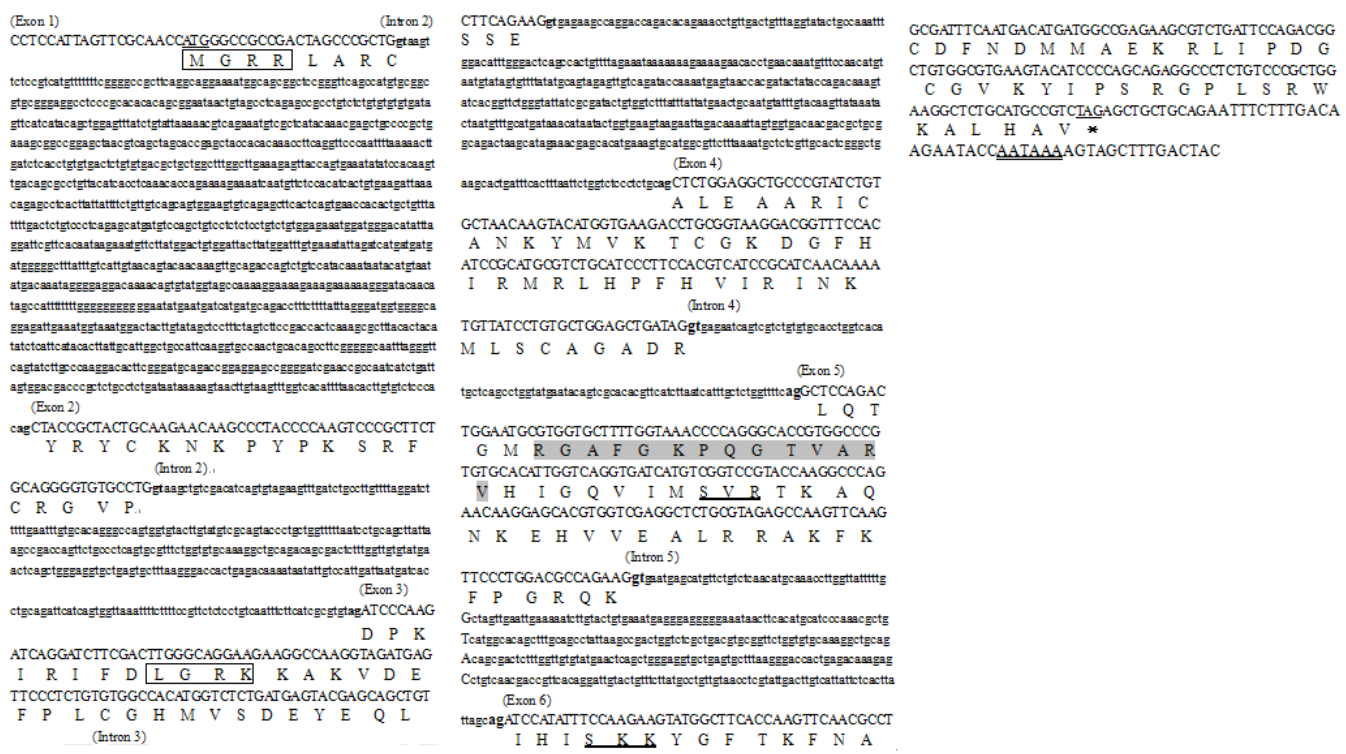

Figure 2. Full-length of the PcQM cDNA sequence and full-length of the PcQM genomic sequence. The start codon (ATG), stop codon (TGA) and polyadenylation signal (AATAAA) are underlined. The Exon sequence is capitalized. The deduced amino acid sequences are translated. LGRK and MGRR indicate the acylamidation sites. SVR and SKK indicate protein kinase C phosphorylation sites. RGAFGKPQGTVARV in gray highlighting is the classic ribosomal protein L10 (RPL10).

The PcQM protein contained two acylamidation sites (MGRR, 1-4; LGRK, 36-39), two protein kinase C phosphorylation sites (SVR, 137-139; SKK, 168-170), one $N$-myristoylation site (GMRGAFG, 114-120), and one RPL10 signature (RLRGAFGKPQGTVARV, 116-129) (Figure 2). There were nine cysteines in the protein without disulfide. The average hydrophobicity was -0.517 . No N-terminal signal sequence was found, indicating that PcQM is not a secretory protein. The instability index was 46.05 , indicating the instability of the PcQM protein.

\section{Full-length PcQM genomic sequence}

The PcQM genomic sequence (GenBank accession No. GQ398775) contained 3200 
bp, comprising six exons $(24,57,108,141,162$, and $156 \mathrm{bp})$ and five introns $(1210,344,473$, 96, and $357 \mathrm{bp}$ ) (Figure 2). Several codons encoding aa were divided by the introns; GCT encoding $\mathrm{C}^{8}$ was divided by intron 1 , GAT encoding $\mathrm{D}^{28}$ was divided by intron 2 , and AGC encoding $\mathrm{A}^{64}$ was divided by intron 3 . In introns, $\mathrm{A}+\mathrm{T}$ was $55.60 \%$ and $\mathrm{C}+\mathrm{G}$ was $44.40 \%$, while $\mathrm{A}+\mathrm{T}$ was $44.14 \%$ and $\mathrm{C}+\mathrm{G}$ was $55.86 \%$ in exons. There were many $\mathrm{A} / \mathrm{T}$ repeat structures in the introns, such as 12 TTATT, 3 TTTTT, 1 TTTTTT, 1 TTTTTTT, 4 AAAAA, and 2 AAAAA.

\section{Alignment and phylogenic analysis}

The deduced aa sequences of QM-like proteins from P. crocea and other known aquatic organisms were highly conserved (Figure 3 ). The N-terminus and middle sequences of QM proteins were more conserved than those of the C-terminus sequence. The P. crocea QM-like gene was more closely associated with those from other teleosts than with marine invertebrates (Figure 4). PcQM shared 99.1, 97.7, 97.7, 96.3, 95.8, 94.9, 94.4, 91.6, 91.6, 91.2, 86.0, 79.6, 79.5, 79.0, 78.6, 77.9, 77.9, 77.6, and 76.2\% sequence identity with the QM-like proteins from S. ocellatus, T. nigroviridis, Solea senegalensis, C. idella, D. rerio, I. punctatus, I. furcatus, E. lucius, S. salar, O. masou formosanus, P. marinus, S. purpuratus, $H$. discus discus, B. floridae, H. diversicolor supertexta, M. japonicus, P. monodon, P. fucata, and P. martensi, respectively (Figure 5).

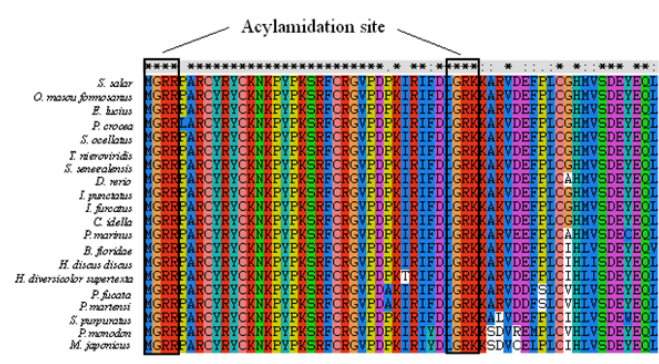

N-myristoylation site

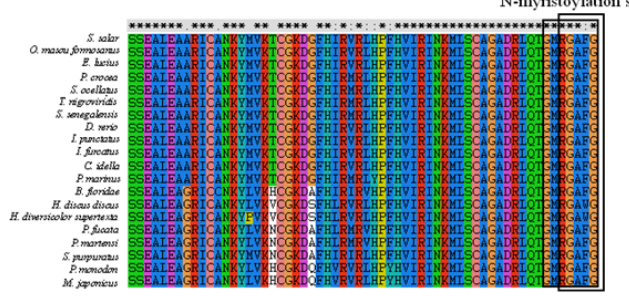

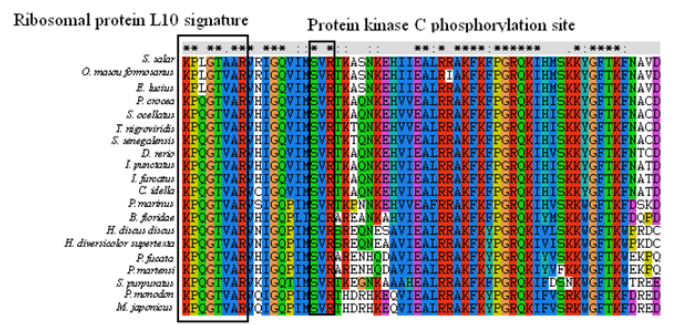

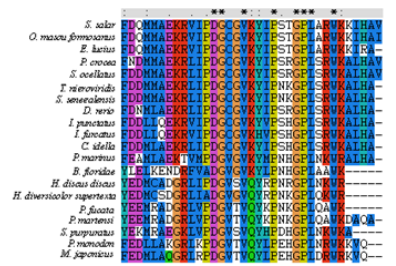

Figure 3. Alignment of deduced amino acid sequences of PcQM (GQ398775) from Pseudosciaena crocea with those of QM-like from Branchiostoma floridae (XP002595777), Ctenopharyngodon idella (AAV31599), Danio rerio (NP956321), Esox lucius (ACO14449), Haliotis discus discus (ABO26700), H. diversicolor supertexta (ACJ71721), Ictalurus furcatus (ADO28202), I. punctatu (AAK95135), Marsupenaeus japonicas (ABS45569), Oncorhynchus masou formosanus (ABY28368), Pinctada fucata (AAQ09228), Petromyzon marinus (AAN73368), Pinctada martensi (ABQ23588), Penaeus monodon (ACV72062), Sciaenops ocellatus (ACS93603), Strongylocentrotus purpuratus (XP787854), Salmo salar (ACN12558), Solea senegalensi (BAF98656), and Tetraodon nigroviridis (CAF90584). *Significant identity; ":” = significant similarity. 


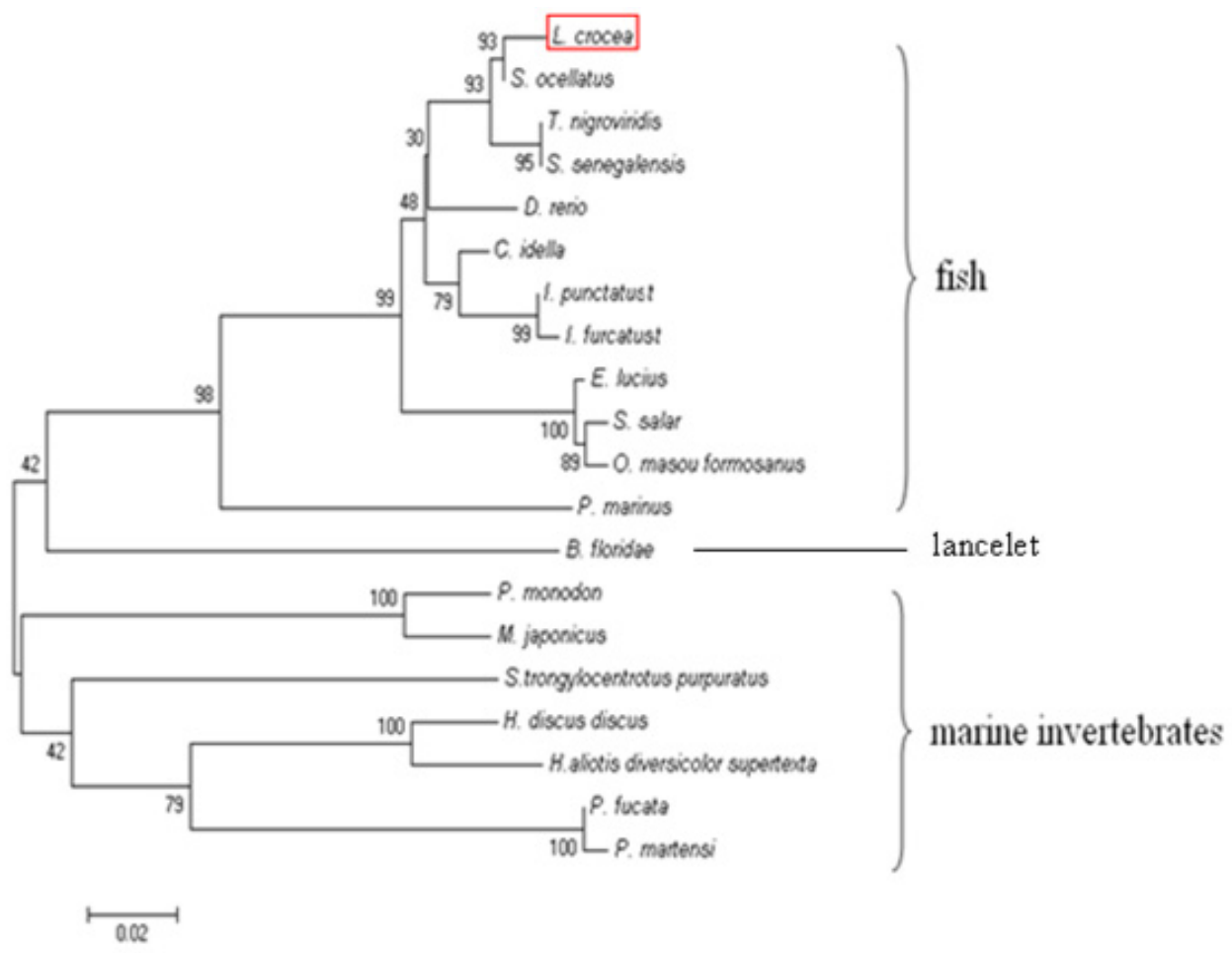

Figure 4. Construction of the phylogenic tree using the neighbor-joining method by the Mega 4.0 software based on amino acid sequences of the QM-like gene in known aquatic organisms. See Figure 3 for species full names in GenBank. A bootstrap analysis relating to nodes was based on 1000 replicates.

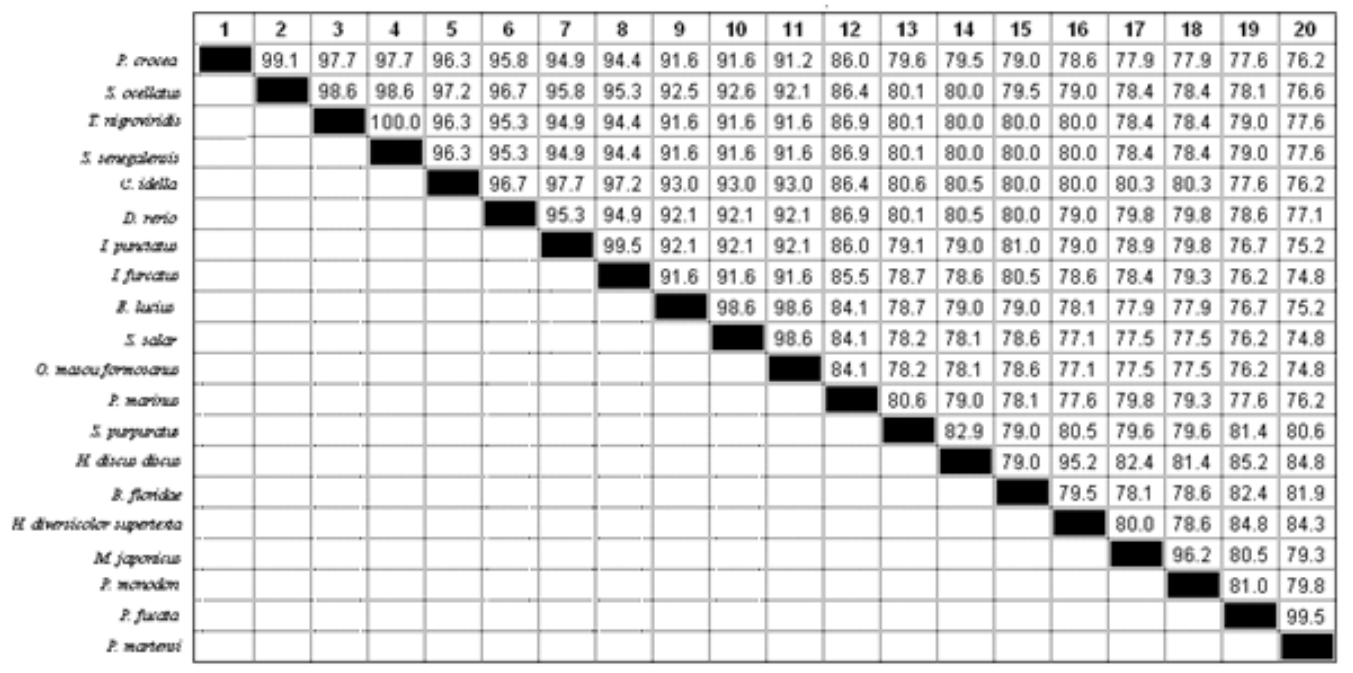

Figure 5. Matrix indicating the percentage identities of the aligned QM-like proteins in the known aquatic organisms. See Figure 3 for species full names. 


\section{DISCUSSION}

The QM-like gene has been widely reported in organisms from plants to mammals (Chavez-Rios and Vargas-Mejia, 2000; Hwang et al., 2000; Green et al., 2000). Studies of the QM-like gene in aquatic organisms have focused on shellfishes (Oh et al., 2010), crustaceans (Xu et al., 2008; Zhou et al., 2011), and freshwater fishes (Wen et al., 2005). Increasing evidence has shown that the QM-like gene has important immune functions in organisms (Wen et al., 2005; Rocha et al., 2008; Oh et al., 2010). This study has, for the first time, isolated and identified the full-length PcQM from a marine fish, $P$. crocea, and tested its immune role through a bacterial challenge experiment.

The fish gill is not only a respiratory organ, but also a major organ of the mucosal immune system for producing antibody-secreting cells (dos Santos et al., 2001), MHCII (Koppang et al., 2003), CD83 (Ohta et al., 2004), and epithelial lymphocytes (Haugarvoll et al., 2008). Based on microarray analysis and real-time PCR, the expression level of PcQM in this study was significantly downregulated in the $P$. crocea gill after challenge with $V$. harveyi and $V$. alginolyticus, suggesting that PcQM plays an immune-modulatory role to protect the host from pathogens.

The QM-like proteins from other aquatic organisms also demonstrated this immune role. The GcQM gene from the grass carp C. idella, as an inflammatory, stress-inducible gene associated with antibacterial and viral defense mechanisms, was upregulated by Aeromonas hydrophila bacteria and grass carp hemorrhagic virus (Wen et al., 2005). The PjQM gene from the shrimp Penaeus japonicus was significantly upregulated in virus-resistant individuals and could regulate the activity of phenol oxidase, a key enzyme in the prophenoloxidation activation system of invertebrate immunity (Xu et al., 2008). In the abalone $H$. discus discus challenged by bacteria and virus, the AbQM gene in the gill exhibited significant upregulation (Oh et al., 2010). A gradual decrease of AbQM transcript was identified in hemocytes after VHSV challenge. The AbQM gene in $H$. discus discus responded to and facilitated a defensive effect against the pathogens.

The aa sequences of QM-like proteins from aquatic organisms are highly conserved. The full-length cDNA of PcQM contains a 648-bp ORF coding for a 215 -aa protein with a $24.5-\mathrm{kDa}$ molecular mass and 10.48 isoelectric point. The GcQM protein contains 218 aa with an isoelectric point of 10.2, and the AbQM protein contains 218 aa with an isoelectric point of 10.2 (Wen et al., 2005; Oh et al., 2010). PcQM, GcQM, and AbQM all have characteristic motifs of QMs, i.e., an RPL10 signature (RGAFGKPQGTVARV) and protein kinase C phosphorylation sites. Similar to GcQM and AbQM, Signal P3.0 analysis revealed that PcQM has no signal peptide, suggesting that these are not secretory proteins. The percentage identities of PcQM with GcQM and AbQM were 96.3 and $79.5 \%$, respectively, indicating that the functions of PcQM and GcQM are more similar than that of AbQM, and the difference may stem from the differing immune systems of teleosts and shellfishes (Tanguy et al., 2004; Workenhe et al., 2010).

The PcQM genomic sequence contained many A/T repeat structures. The A/T-rich region in the chromosome has a regulation function during gene transcription and expression, suggesting that the introns of the PcQM genomic sequence play a significant regulation function during PcQM transcription.

In summary, the QM-like proteins from aquatic organisms are highly conserved and have similar immune functions. 


\section{ACKNOWLEDGMENTS}

Research supported by the Special Fund for Agro-Scientific Research in the Public Interest (\#200903029), the Natural Science Research Program of Universities in Jiangsu Province, China (\#12KJD240001) and the "Famous Abroad Teacher" Program of Jiangsu, China [\#(2011)212].

\section{REFERENCES}

Chavez-Rios R and Vargas-Mejia M (2000). Isolation and identification of L10 gene from Entamoeba histolytica homologous to Wilms' tumor suppressor. Arch. Med. Res. 31: S305-S306.

Chen X, Wu CW, Zhong SP, Zeng FR, et al. (2011). Molecular characterization and structure analysis of RPL10/QM-like protein from the red drum Sciaenops ocellatus (Sciaenidae). Genet. Mol. Res. 10: 576-587.

Chou MY, Hsiao CD, Chen SC, Chen IW, et al. (2008). Effects of hypothermia on gene expression in zebrafish gills: upregulation in differentiation and function of ionocytes as compensatory responses. J. Exp. Biol. 211: 3077-3084.

dos Santos NM, Taverne-Thiele JJ, Barnes AC, van Muiswinkel WB, et al. (2001). The gill is a major organ for antibody secreting cell production following direct immersion of sea bass (Dicentrarchus labrax, L.) in a Photobacterium damselae ssp. piscicida bacterin: an ontogenetic study. Fish Shellfish Immunol. 11: 65-74.

Dowdy SF, Lai KM, Weissman BE, Matsui Y, et al. (1991). The isolation and characterization of a novel cDNA demonstrating an altered mRNA level in nontumorigenic Wilms' microcell hybrid cells. Nucleic Acids Res. 19: 5763-5769.

Eisinger DP, Dick FA and Trumpower BL (1997). Qsrlp, a 60S ribosomal subunit protein, is required for joining of 40S and 60S subunits. Mol. Cell Biol. 17: 5136-5145.

Green H, Canfield AE, Hillarby MC, Grant ME, et al. (2000). The ribosomal protein QM is expressed differentially during vertebrate endochondral bone development. J. Bone Miner. Res. 15: 1066-1075.

Haugarvoll E, Bjerkas I, Nowak BF, Hordvik I, et al. (2008). Identification and characterization of a novel intraepithelial lymphoid tissue in the gills of Atlantic salmon. J. Anat. 213: 202-209.

Hwang JS, Goo TW, Yun EY, Lee JH, et al. (2000). Tissue-/stage-dependent expression of a cloned Bombyx mandarina QM homologue. Biomol. Eng. 16: 211-215.

Jin S, Cai WQ and Wang GL (2002). Studies on the pathogenic bacteria diseases of cultured Pseudosciaena crocea. J. Zhejiang Ocean Univ. 21: 225-230.

Kaneko K, Kobayashi H, Onodera O, Miyatake T, et al. (1992). Genomic organization of a cDNA (QM) demonstrating an altered mRNA level in nontumorigenic Wilms' microcell hybrid cells and its localization to Xq28. Hum. Mol. Genet. 1: 529-533.

Koppang EO, Hordvik I, Bjerkas I, Torvund J, et al. (2003). Production of rabbit antisera against recombinant MHC class II $\beta$ chain and identification of immunoreactive cells in Atlantic salmon (Salmo salar). Fish Shellfish Immunol. 14: 115-132.

Li N, Yang Z, Bai J, Fu X, et al. (2010). A shared antigen among Vibrio species: outer membrane protein-OmpK as a versatile Vibriosis vaccine candidate in Orange-spotted grouper (Epinephelus coioides). Fish Shellfish Immunol. 28: 952-956.

Liu M and Sadovy de Mitcheson Y (2008). Profile of a fishery collapse: why mariculture failed to save the large yellow croaker. Fish Fish. 9: 219-242.

Livak KJ and Schmittgen TD (2001). Analysis of relative gene expression data using real-time quantitative PCR and the 2(-Delta Delta C(T)) Method. Methods 25: 402-408.

Mao Y, Xu B, Su YQ, Zhang ZW, et al. (2010). Cloning and mRNA expression of macrophage migration inhibitory factor $(M I F)$ gene of large yellow croaker (Pseudosciaena crocea). Acta Oceanol. Sin. 29: 63-73.

Oh C, De Zoysa M, Nikapitiya C, Whang I, et al. (2010). Tumor suppressor QM-like gene from disk abalone (Haliotis discus discus): molecular characterization and transcriptional analysis upon immune challenge. Fish Shellfish Immunol. 29: 494-500.

Ohta Y, Landis E, Boulay T, Phillips RB, et al. (2004). Homologs of CD83 from elasmobranch and teleost fish. J. Immunol. 173: 4553-4560.

Rocha CS, Santos AA, Machado JP and Fontes EP (2008). The ribosomal protein L10/QM-like protein is a component of the NIK-mediated antiviral signaling. Virology 380: 165-169.

Sambrook J and David WR (2001). Molecular Cloning 3. Cold Spring Harbor Laboratory Press, Cold Spring Harbor.

Scotto-Lavino E, Du G and Frohman MA (2006). 5' end cDNA amplification using classic RACE. Nat. Protoc. 1: 2555-2562.

Tanguy A, Guo X and Ford SE (2004). Discovery of genes expressed in response to Perkinsus marinus challenge in 
Eastern (Crassostrea virginica) and Pacific (C. gigas) oysters. Gene 338: 121-131.

Tobback E, Hermans K, Decostere A, Van den Broeck W, et al. (2010). Interactions of virulent and avirulent Yersinia ruckeri strains with isolated gill arches and intestinal explants of rainbow trout Oncorhynchus mykiss. Dis. Aquat. Organ. 90: 175-179.

Wang J, Su YQ, Zhang ZX, Li M, et al. (2001). Bacterial pathogenetic biology of cultured Pseudosciaena crocea in southern Fujian. J. Xiamen Univ. 40: 85-91.

Wen Y, Shao JZ, Pan XX and Xiang LX (2005). Molecular cloning, characterization and expression analysis of QM gene from grass carp (Ctenopharyngodon idellus) homologous to Wilms' tumor suppressor. Comp. Biochem. Physiol. B Biochem. Mol. Biol. 141: 356-365.

Wool IG (1996). Extraribosomal functions of ribosomal proteins. Trends Biochem. Sci. 21: 164-165.

Workenhe ST, Rise ML, Kibenge MJ and Kibenge FS (2010). The fight between the teleost fish immune response and aquatic viruses. Mol. Immunol. 47: 2525-2536.

Xu J, Wu S and Zhang X (2008). Novel function of QM protein of shrimp (Penaeus japonicus) in regulation of phenol oxidase activity by interaction with hemocyanin. Cell Physiol. Biochem. 21: 473-480.

Zhou F, Jiang S, Huang J, Qiu L, et al. (2011). Molecular analysis of the QM gene from Penaeus monodon and its expression on the different ovarian stages of development. Mol. Biol. Rep. 38: 1921-1927. 